\section{Hearty fare?}

\section{Coronary Artery Disease: Genes, Drugs, and the Agricultural Connection \\ by Ole Færgeman \\ Elsevier: 2003. 152 pp. ०50, \$50}

\section{Marion Nestle}

We can prevent coronary artery disease (CAD), says Ole Færgeman, professor of preventive cardiology at the University of Aarhus in Denmark. All we have to do is stop smoking cigarettes and stop eating the meat and milk of large domesticated land mammals. As Færgeman argues in this intriguing, provocative and sometimes maddening book, "producing huge numbers of animals for human food is at the core of the problems of agriculture, medicine, and global food security". If we fail to grasp the evils of animal agriculture, it is because "the love of milk has been etched into our genome", the "medico-industrial complex" promotes disease treatment rather than prevention, and powerful agricultural interests profit from our love of meat and dairy foods.

Never mind that agriculture brought us stability and abundant calories. It also brought vitamin and mineral deficiencies (due to a lack of food diversity), infectious diseases (acquired from animals), and poverty (from dependence and low wages). Agriculture is "the most environmentally destructive of all human activities", wasting nitrogen - which causes "hypoxia in the sea as well as in the human heart muscle" eroding soil, and is so inefficient that only $10 \%$ of the energy in fertilizer, tillage and transport is converted to food. "A doctor's prescription for a better environment would be to lower the number of livestock... As a side-effect, it would reduce heart disease."

Before dismissing such contentions as absurdly exaggerated, ponder Færgeman's initial questions. When did CAD become an important cause of mortality, and why? How well do we understand its response to dietary factors? Why do we prefer to fund research on the genetics of CAD rather than its behavioural determinants? How does evidencebased medicine affect our understanding of the social, political and agricultural causes of CAD? And how can we answer such questions when research is so often sponsored by self-interested industries?

Færgeman brings plenty of clinical experience to bear on these issues. He has witnessed the effects of saturated animal fat on blood cholesterol levels, of blood cholesterol on plaque formation, and of plaque rupture on coronary thrombosis. Epidemiological studies "clinch the arguments": populations consuming food from land mammals have

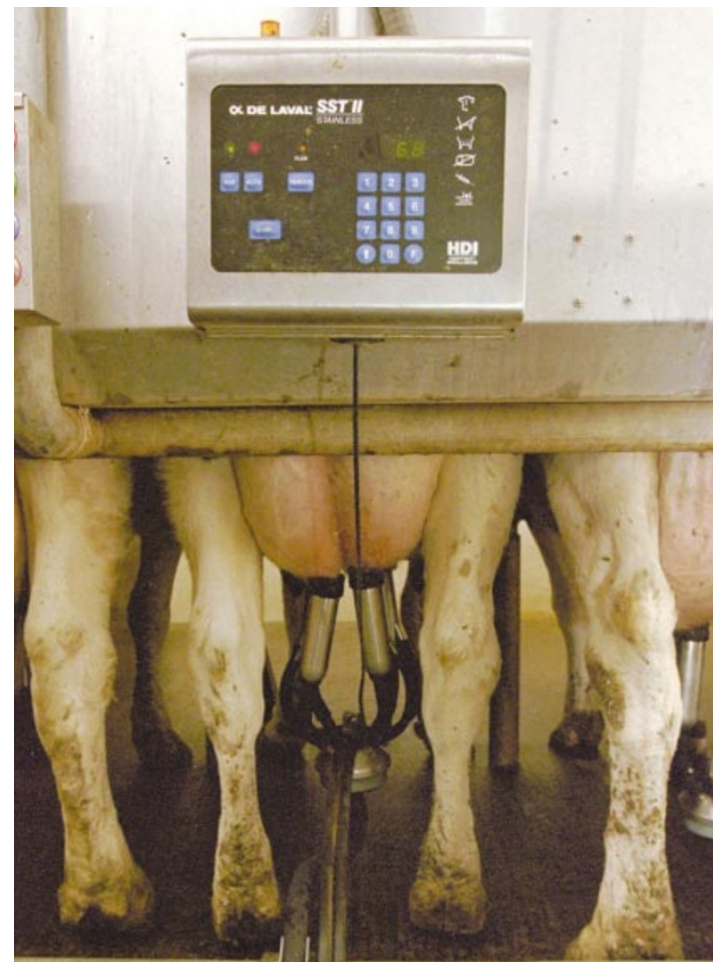

Milk bar? Ole Færgeman believes that reducing our intake of dairy products will prevent coronary artery disease.

higher rates of CAD but live longer when they replace beef and butter with fruits, vegetables, nuts and fish. Plant-based diets not only lower blood cholesterol but also protect against arterial inflammation, endothelial malfunction and disturbances of heart rhythm. Drugs help, but they address symptoms, not causes. Genetics matters, but not much: possessing the wrong genes rarely causes CAD unless people also eat meat and drink milk.

I am guessing that Færgeman is not a vegan, but such statements make him sound like one. The book's startling cover image, derived from Nordic myth, depicts a rather well-endowed man suckling milk from a cow. Adults, he says, are not supposed to drink milk. Evolution ensures that infants wean; most people lose the ability to digest lactose (milk sugar) after early childhood. The rare persistence of lactase in certain populations is "perhaps the most important single genetic determinant of risk of coronary artery disease". If people fight evolution by continuing to drink milk, it is because the medico-industrial complex labels lactase "deficiency" as a genetic disorder and the dairy industry has convinced us that its products are essential.

I am at a loss to decide whether Færgeman would make a lively or tedious dinner companion. He writes well, but digresses. Along with matters clearly germane to $\mathrm{CAD}$, he discusses theories of biological complexity, Danish history, the career of Tycho Brahe, Prozac, psychological debriefings, gallstone surgery, anaesthesiology and the fractal coastline of California. Such digressions slow the pace and detract from the core arguments, which are much more fun. He rails against the politics of medicine, the influence of corporations on universities and the limitations of science in answering questions about behaviour and health. He worries about how science is corrupted by the meat, dairy, tobacco and pharmaceutical industries and how evidencebased medicine is inadequate to deal with the environmental causes of disease. He agrees that clinical trials make good science but regrets that they leave few resources for studying the political, societal and agricultural context of disease.

Alas, Færgeman offers few solutions to these problems. Unless we change our ways, he warns, the unwise will continue to succumb to CAD, and agriculture will continue to determine the need for cardiologists and heart surgeons. Governments should integrate health and agricultural policies, researchers should study social determinants of disease, and universities should remain independent of corporate influence. It's up to us, he says, to "develop the political will to ... protect nature and to promote human health and sanity". Yes, but how? This book is about policy, not dietary practices or political advocacy, and Færgeman leaves us on our own to work out how to apply his important lessons.

Marion Nestle is in the Department of

Nutrition, Food Studies, and Public Health, New York University, New York,

New York 10012-1172, USA

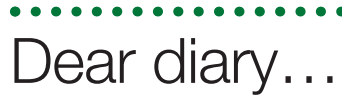

\section{Science, Not Art: Ten Scientists' Diaries \\ edited by Jon Turney \\ Calouste Gulbenkian Foundation: 2003. \\ 160 pp. $£ 8.50$}

\section{Nancy Rothwell,} with Siobhan Blagbrough

The title of this book is quite misleading. Science, Not Art conjures up visions of a contribution to the topical debate on the similarities, differences and distinctions between science and the arts. But it's not about that at all, as clearly stated in the preface. Its title arises from an earlier popular book, Art, Not Chance, which was produced by the same 


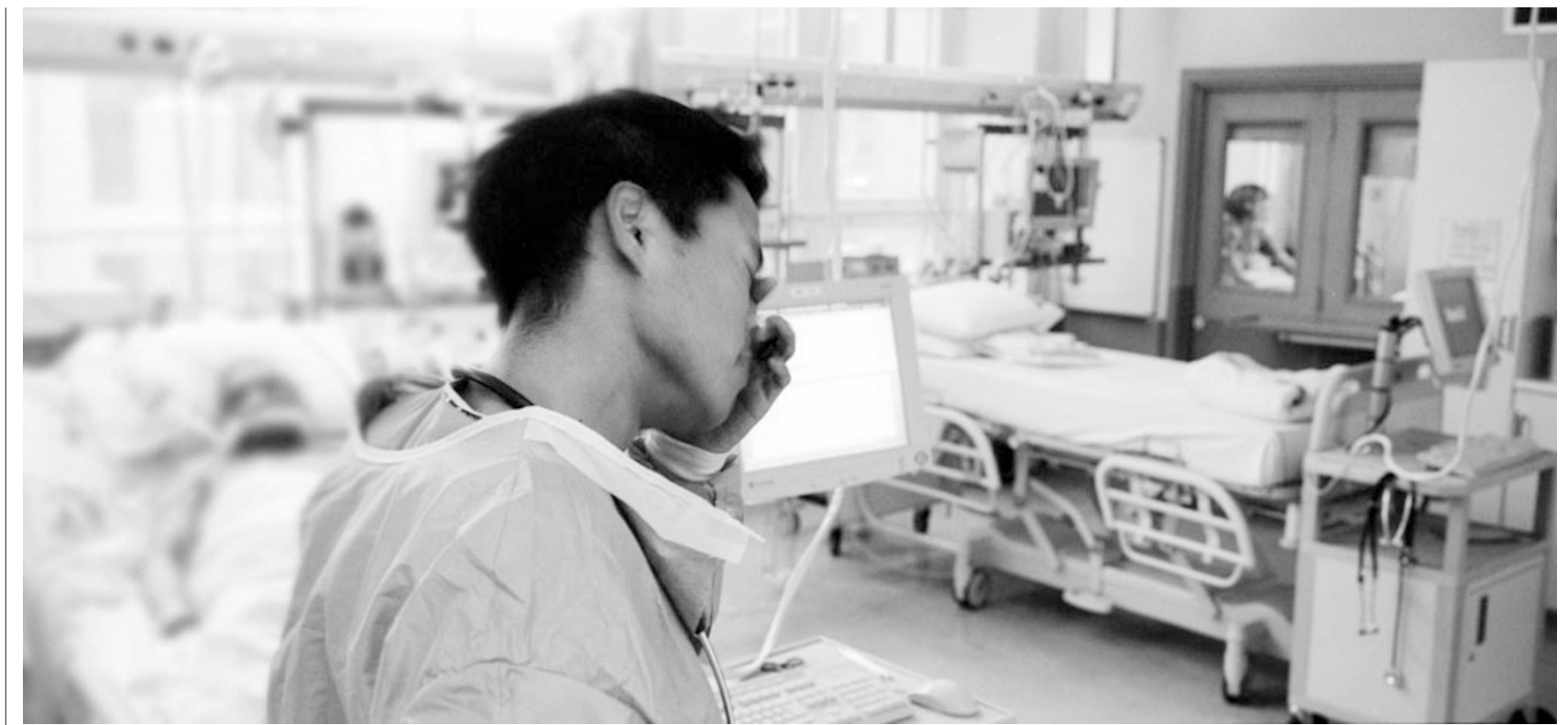

Under pressure: space physiologist Kevin Fong feels the strain of combining studies of astronauts' health with life as a junior doctor at a London hospital.

publisher and comprised extracts from the diaries of nine leading artists.

Science, Not Art follows the same pattern, with short passages from the diaries of ten scientists, accompanied by excellent photographs by Hugo Glendinning. The individuals may not yet be world leaders in their fields, but they are certainly not "ordinary young scientists". Many hold prestigious Royal Society University Research Fellowships in disciplines encompassing mathematics, cosmology, biology, chemistry and medicine. The scientists also challenge the title of the book, as many have strong links with art, music and popular science writing. Two hold fellowships from the National Endowment for Science, Technology and the Arts, which are awarded to creative individuals, particularly for work spanning science and arts. Several have formal links with the arts and artists.

The diaries are well written and engaging, and are all very different in style. Some of the scientists focus mainly on their research, whereas others play heavily on their personal lives and the tensions between a heavy workload and family life. Some are in note form; others tell fascinating stories. Particularly engaging are the tales of Jon Copley, a marine biologist encountering a storm on a scientific voyage, and the experiences of Kevin Fong, a young clinical researcher, in a busy intensive-care unit in a London hospital.

Most remarkable are the common features of the diaries. The scientists all write of pressure, devotion and great commitment, the depressing lows and great highs accompanying failure and success in their scientific lives - and these often seem to have greater impact than personal events. They all tell of the importance of working with people, of the excitement of discovery, and of the despair that follows unsuccessful grant applications, substandard scientific presentations and poor reviewers' comments on submitted manuscripts.

The audience for this book is not obvious. Scientists will enjoy the comparisons and familiarity of many of the stories, and feel relief at the shared problems and concerns, but the nature of the book and its clear, jargon-free explanation of science should attract non-scientists. To test this, I asked a 16-year-old, Siobhan Blagbrough, who has no current aspiration to enter science, for her opinion.

"I found the book interesting and surprisingly easy to read. While dealing with scientific concepts beyond my understanding, the personal approach and diary format meant that there was usually something to keep me interested. The way that the different scientists became involved in their field, sometimes without following the expected academic route, made me think that their success stems more from their determination to find solutions to questions that on the face of it may appear trivial or at least of little apparent value. But they can see how these fit into a bigger picture and may lead to a major breakthrough.

"To read how they cope with daily life and problems but still have the determination to overcome this and work so hard on their various projects is quite inspiring. I also found exciting the way that many of them travel all over the world, meeting other scientists to learn from each other.

"I would say that the book gave me an insight into these scientists' lives and how, in many aspects, they are similar to everyone else, fearing failure or rejection but perhaps having more dedication, determination and vision than most."
This summary is perhaps a better recommendation than I could make.

Nancy Rothwell is at the School of Biological Sciences, University of Manchester,

Oxford Road, Manchester M13 9PT, UK.

\section{Quantity control \\ Measure for Measure: The Story of Imperial, Metric, and Other Units by Alex Hebra \\ Johns Hopkins University Press: 2003. \\ 232 pp. \$24.95, $£ 18.50$ \\ David Lindley}

In the United States people take their temperatures in Fahrenheit and, more mysteriously, rate their air-conditioners in British thermal units (Btus). Experience shows that it takes a few thousand Btus to cool a typical room (volume measured in cubic feet, of course, and let me not get started on the fact that we build our houses using two-byfours whose cross-section is an inch and a half by three-and-a-half inches). Scientists may find this lamentable, but in everyday use scientific units have no particular advantage. Working in approved units, you would have to buy an air-conditioner with a capacity (pause while reviewer uses Google to find the definition of Btu) of some number of megajoules. To the average shopper, this is equally incomprehensible.

In this haphazard and only fitfully engaging book, Alex Hebra conveys clearly enough that convenience and tradition account for the origin of most of the units we use, as well as the fact that even scientists haven't completely fallen in line with the Système Internationale. Cosmologists insist 